\title{
Are Consumers More Willing to Pay for Digital Items in Mobile Applications? Consumer Attitudes toward Virtual Goods
}

\author{
Yu-Chen Yang \\ Department of Information Management \\ National Sun Yat-sen University, Kaohsiung, Taiwan \\ ycyang@mis.nsysu.edu.tw \\ Li-Ting Huang \\ Department of Information Management \\ Chang Gung University, Taoyuan, Taiwan \\ Division of Physical Medicine and Rehabilitation \\ Chang Gung Memorial Hospital in Linkuo, Taoyuan, Taiwan \\ lthuang@mail.cgu.edu.tw \\ Yu-Ting Su \\ Department of Information \\ E.SUN Commerical Bank, Taipei, Taiwan \\ mimy0217@gmail.com
}

\begin{abstract}
Virtual goods are usually classified as services. The popular instant messenger LINE, with its stickers, is one of the most successful business models for virtual goods. Our study explores the intention to purchase virtual goods and examines the critical successful factors in LINE stickers. We propose a theoretical model based on perceived value, satisfaction, personal innovativeness, and reference group acceptance. Our key findings reveal (1) the significant influence of individual perception, personal characteristics, and social influence and (2) the key role of personal innovativeness in in-app purchases using mobile social media.
\end{abstract}

Keywords: App Service, Virtual Good, Purchase Intention, Value-based Adoption Model

Citation: Yang, Y. C., Huang, L. T. and Su, Y. T. (2017). " Are Consumers More Willing to Pay for Digital Items in Mobile Applications? Consumer Attitudes toward Virtual Goods," Pacific Asia Journal of the Association for Information Systems, 9(4), pp. 51-64. 


\section{Introduction}

Virtual goods are usually classified as services and intangible objects. Consumers purchase virtual goods for use in online games or online communities. Virtual goods include digital gifts, virtual money, and digital weapons for online game players. Virtual goods can be reproduced and distributed with almost zero cost and are immediately available to consumers via online channels. With the rapid development of the Internet, virtual goods have become widely used in social software and present new opportunities for electronic commerce (Lehdonvirta, 2009).

Virtual goods business models fall into the following categories: subscription, retailing, and freemium (Alvarez, 2012; Koeder \& Tanaka, 2017). In the subscription business model, consumers pay a subscription fee to gain the right to access the service; for example, online gamers pay a predetermined fee for monthly access to games. The retailing business model allows firms to sell virtual goods via either an online or physical channel. Consumers can purchase access codes via official websites, apps, or physical stores and use them to access virtual goods. For example, Tencent Holdings Limited is one of the largest web portals in China and is best-known for its instant messenger application Tencent $Q Q$. Tencent sells an online currency, $Q$ coins, which consumers purchase to pay for Tencent's services and virtual goods. $Q$ coins are obtained by purchasing a prepaid card via either a mobile service or a thirdparty payment service such as PayPal. Finally, freemium is a business model in which a basic product or service is offered free of charge, but its consumers are charged for a premium version or for virtual goods. The instant messenger LINE is offered for free for instant communication such as texts, images, video, and audio as well as for free VolP calls and video conferencing. LINE stickers are the most significant feature of the service. Consumers can download free stickers for use in their instant communications and to pay for more personalized ones.

Among these three business models, freemium is reported to be the most profitable and most effective for companies selling virtual goods (App Annie, 2015). Freemium services represent a mobile app revenue-generating juggernaut, having increased their revenue $211 \%$ from 2012 to 2013. Moreover, $83 \%$ of the top 1,000 apps on the iOS App Store and the top 1,000 apps on Google Play are using the freemium business model. Freemium services comprised $92 \%$ of total mobile app revenue across both stores in 2013. The freemium business model is not only widely used in gaming but has rapidly expanded into non-game mobile apps such as messaging and music. LINE leads the revenue ranking for such non-game apps. The virtual goods LINE offers, its stickers, have two special features. First, both free and paid stickers are available to consumers, but people are still willing to pay for stickers even though they are able to choose free ones. Second, consumers are allowed to create and sell their own stickers through the LINE Creators Market. More than 100,000 packs of stickers have been available on this market since it opened in May 2014. The average revenue of the top 10 stickers has reached 36.8 million Japanese yen. Some companies have even created free stickers as gifts for consumers to promote their products or brands. Due to these features, LINE stickers have contributed to the huge increase in LINE revenue and are generating a unique LINE sticker economy.

The case of LINE stickers appears to be the most successful among the business models for virtual goods. The popularity of stickers is driving huge profits along with innovative marketing techniques. Consumers can obtain stickers via either free downloads or online payments. Many consumers are willing to pay for LINE stickers even though they can download some stickers for free. This study explores the factors that influence consumers to 
purchase LINE stickers even through some stickers are available for free. The remainder of this paper is organized as follows. Section 2 reviews the relevant literature and outlines the study's empirical model. Section 3 addresses our key research question and investigates consumer intention to purchase virtual goods. Section 4 concludes the paper by summarizing the managerial insights of our analyses and providing possible directions for future study.

\section{Relevant Literature and Hypothesis Development}

We explore the intention to purchase virtual goods by, first, introducing the concept of "virtual purchase" and summarizing the research on it. Our research framework is based on the Value-based Adoption Model (VAM; Kim et al., 2007) and incorporates related studies, such as work on purchase satisfaction, reference group acceptance, and personal innovativeness. The conceptual framework of this study is illustrated in Figure 1.

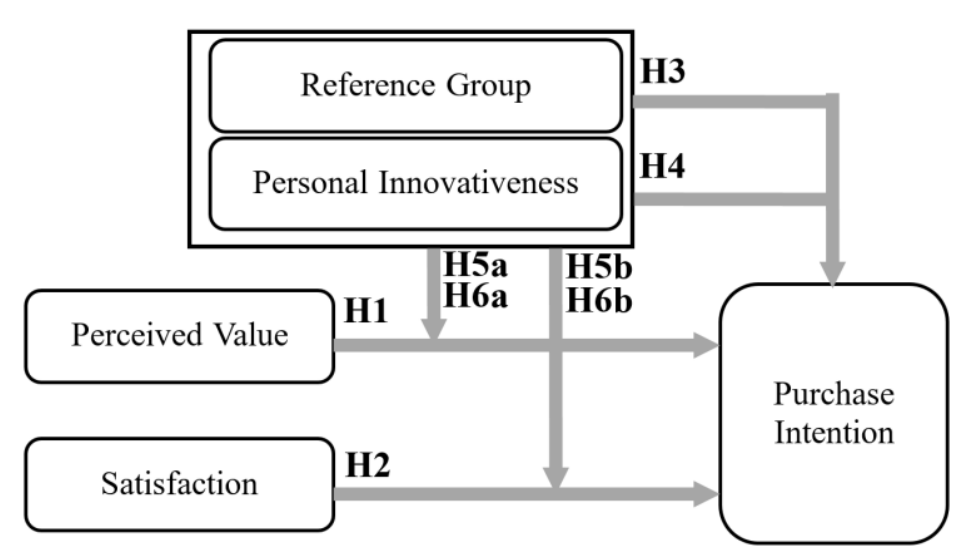

\section{Figure 1 - Proposed research framework}

\section{Virtual Purchase Behavior}

Hamari (2017) investigates purchase behavior for virtual goods in three different types of free-to-play games. The study finds that (1) enjoyment of the game reduces the willingness to buy virtual goods while increasing the willingness to play more of the game; and (2) attitude to virtual goods and beliefs about peer attitudes strongly increase the willingness to purchase virtual goods. Jung and Pawlowski (2014) explore consumer goals for virtual consumption and develop a virtual liminoid theory to explain the transitions between users' real-world and virtual identities and virtual consumption as a transition catalyst. Animesh et al. (2011) explore the impacts of technological and spatial environments on intention to purchase virtual products.

According to Jung and Pawlowski (2014), virtual worlds can be categorized into gaming and social virtual worlds (SVWs). Bray and Konsynski (2007) show that SVWs have altered many features of human life, such as education, business, social events, corporate meetings, social networking, and e-commerce. The research suggests that information is the main factor in ecommerce purchase behavior (Wolfinbarger and Gilly, 2001); customers need to be satisfied with the available information concerning their online purchases (Park and Kim, 2003). Lehdonvirta (2009) divides the purchase drivers for virtual items into three conceptual categories: (a) functional, (b) 
hedonic, and (c) social. Animesh et al. (2011) categorize consumers' virtual goods purchase behaviors in virtual worlds into two key dimensions: technology and spatial.

\section{Perceived Value and Value-based Adoption Model (VAM)}

Perceived value is defined as "the consumer's overall assessment of the utility of a product based on perceptions of what is received and what is given" (Zeithaml, 1988). Consumers have varying perceptions of the value of products and services. For example, some may prefer high-quality products/services, while some may prefer high volumes (Zeithaml, 1988). Viewing value as the balance achieved between standard and cost is too facile (Bolton and Drew, 1991). Value is more independent and distinctive than quality and is therefore a higher-level concept (Zeithaml, 1988). Sweeney and Soutar (2001) divide perceived value into four dimensions: sentimental, collective, standard/ performance, and cost/worth. In an online environment, perceived value is a mediating variable in the relationship between online trust and purchase intention (Chong et al., 2003). Kim et al. (2007) propose the VAM by integrating the Technology Adoption Model (TAM) with the perceived value literature and empirically test the proposed model in subsequent studies. For example, Kim et al. (2012) examine the intention to purchase digital items based on the theory of self-presentation, while the analysis in Kim et al. (2011) is based on customer value theory. Their findings show that emotional and social factors are two key drivers of the intention to purchase digital goods in social networking communities. From the value-maximization perspective, the VAM model has also been utilized to examine Korean consumers' Software as a Service (SaaS) adoption (Kwon and Seo, 2013). Considering the relationship between perceived value and purchase intention, we derive the following hypothesis:

$\mathrm{H} 1$. Perceived value is positively associated with purchase intention.

\section{Satisfaction}

Customer satisfaction is a marketing term that emphasizes delivering satisfaction to consumers and obtaining profits in return. It is used to measure how a company's products and services fulfill or exceed customer expectation. Customer satisfaction research developed as a distinct area of marketing theory in the 1970s (Oliver, 1980; Churchill and Surprenant, 1982). The model of Oliver (1980), integrated with familiar disconfirmation theory, is the most influential customer satisfaction model. According to Oliver (1980), consumers compare a product with their expectations about product performance to judge their satisfaction level. $\mathrm{He}$ finds that disconfirmation is positively related to consumer satisfaction. Verhagen et al. (2011) explore virtual item satisfaction and address two intrinsic (escapism and entertainment) and two extrinsic (economic value and ease of use) experiential values. Following the insights in Oliver (1980), essential for business in today's marketplace, and the work of Verhagen et al. (2011) on virtual worlds, the following hypothesis is proposed.

$\mathrm{H} 2$. Satisfaction is positively associated with purchase intention.

\section{Reference Group Acceptance}

The original definition of "reference group" occurs in Turner (1956): "a reference group may mean a group with which one compares himself in making a selfjudgement." The term "reference group" is usually used to explain how social groups influence individual values, attitudes, and behavior (Blackwell et al., 2001). The literature explores the effect on purchase intention of reference groups. Kotler (1994) indicates that the reference group is a key factor influencing consumers' purchase decisions. Hoonsopon and Puriwat (2016) examine the roles of reference groups (private and public) on the purchase intentions of several types of shoppers. They find that a reference group (especially 
a private one) impacts the purchase intention of utilitarian buyers. Therefore, we propose the following:

H3. Reference group acceptance is positively associated with purchase intention.

\section{Personal Innovativeness}

Personal innovativeness usually refers to the belief that an individual is open to new IT. The concept of personal innovativeness was introduced in an IS context by Agarwal and Prasad (1998), who describe personal innovativeness as the inclination to adopt an innovation. Their findings show that personal innovativeness moderates the relationship between perceptions of a new IT and intentions to use it.

Personal innovativeness affects human behavior from the psychological perspective (Lu, 2014). Jackson et al. (2013) classify personal innovations into five types: (a) relative advantage, the extent to which the new, innovative practice is better than the former practice; (b) compatibility, the extent to which adopting the innovation is appropriate for the individual; (c) complexity, the extent to which the innovation is recognize as being difficult to utilize; (d) observability, the extent to which the outcomes of the innovation are noticeable to others; and (e) trialability, the extent to which the innovation can be assessed before the consumer selects or dismisses it. Personal innovativeness has been found to be the strongest predictor of webcasting adoption (Lin, 2006). Parveen and Sulaiman (2008) show that personal innovativeness has a positive impact on intention to use wireless Internet on mobile devices. Since LINE is a mobile app, the following hypothesis is proposed:

H4. Personal innovativeness is positively associated with purchase intention.

\section{Moderating Roles of Reference Group and Personal Innovativeness}

Lin and Chen (2006) report that the relationship between perceived value and intention may become stronger with a high level of reference group acceptance and weaker with a low level. Blackwell et al. (2001) indicate that every person and group significantly influence an individual's purchase decisions and buying behavior. Although consumers may initially perceive that the value of LINE stickers may not be high enough or are not satisfied with them, they may still end up purchasing them due to the influence of their reference group. Yi et al. (2006) show that high individual innovativeness may strengthen the reference group's influence on behavior intention. Individuals with high personal innovativeness have been found to have traits that increase their likelihood of purchasing LINE stickers even if their perceived value or satisfaction is poor. For the above reasons, we propose the following:

H5a. Higher reference group acceptance can strengthen the relationship between perceived value and purchase intention.

$\mathrm{H} 5 \mathrm{~b}$. Higher reference group acceptance can strengthen the relationship between satisfaction and purchase intention.

H6a. Higher personal innovativeness can strengthen the relationship between perceived value and purchase intention.

$\mathrm{H} 6 \mathrm{~b}$. Higher personal innovativeness can strengthen the relationship between satisfaction and purchase intention.

\section{Research Methods and Results}

\section{Data Collection and Sampling}

This study explores consumers' purchase intention for LINE stickers. Most LINE sticker users are in their 20s. Therefore, we collect data from PTT and Facebook between May 13, 2015 and May 27, 2015. 
The study includes 421 participants, from whom 69 responses are removed due to missing values. Hence, the number of valid respondents is 352 . The sample is $46.4 \%$ male and $53.6 \%$ female. Most respondents are young adults from 18 to 34 years of age (88.9\%). Out of 352 records, 270 respondents have purchased stickers on LINE. Table 1 presents the respondents' characteristics.

\begin{tabular}{|c|c|c|}
\hline Measure & Item & $\%$ of respondents (n) \\
\hline Gender & $\begin{array}{l}\text { Male } \\
\text { Female }\end{array}$ & $\begin{array}{l}46.4 \%(163) \\
53.6 \%(189)\end{array}$ \\
\hline Age & $\begin{array}{l}<18 \\
18-24 \\
25-29 \\
30-34 \\
35-39 \\
>39\end{array}$ & $\begin{array}{l}1.1 \%(4) \\
58.5 \%(206) \\
20.5 \%(72) \\
9.9 \%(35) \\
3.7 \%(13) \\
3.3 \%\end{array}$ \\
\hline Education & $\begin{array}{l}\text { High school } \\
\text { College } \\
\text { Graduate }\end{array}$ & $\begin{array}{l}8.8 \%(31) \\
56.2 \%(198) \\
35.0 \%(123)\end{array}$ \\
\hline Average time spent per day with LINE & $\begin{array}{l}\text { Less than } 1 \text { hour } \\
1 \text { to } 2 \text { hours } \\
2 \text { to } 3 \text { hours } \\
3 \text { to } 4 \text { hours } \\
\text { Longer than } 4 \text { hours }\end{array}$ & $\begin{array}{l}26.4 \%(93) \\
28.7 \%(101) \\
20.5 \%(72) \\
7.6 \%(27) \\
16.8 \%(59)\end{array}$ \\
\hline Frequency of sticker use & $\begin{array}{l}\text { Always } \\
\text { Usually/often } \\
\text { Sometimes } \\
\text { Seldom } \\
\text { Never }\end{array}$ & $\begin{array}{l}0.3 \%(1) \\
15.6 \%(55) \\
16.5 \%(58) \\
43.5 \%(153) \\
24.1 \%(85)\end{array}$ \\
\hline Buying LINE stickers & $\begin{array}{l}\text { Yes } \\
\text { No }\end{array}$ & $\begin{array}{l}76.7 \%(270) \\
23.3 \%(82)\end{array}$ \\
\hline Packs of LINE stickers & $\begin{array}{l}\text { Less than } 5 \text { packs } \\
5 \text { to } 10 \text { packs } \\
11 \text { to } 20 \text { packs } \\
21 \text { to } 30 \text { packs } \\
\text { More than } 30 \text { packs }\end{array}$ & $\begin{array}{l}5.9 \%(21) \\
26.6 \%(94) \\
37.3 \%(131) \\
14.2 \%(50) \\
15.6 \%(56) \\
\end{array}$ \\
\hline Way to access to LINE stickers & $\begin{array}{l}\text { Pay by credit cards } \\
\text { Pay by MyCard } \\
\text { Pay by LINE Pay } \\
\text { LINE e-Couples } \\
\text { Gifts } \\
\text { Pay by LINE free coins } \\
\text { Free download for a limited time }\end{array}$ & $\begin{array}{l}22.7 \%(80) \\
25.0 \%(88) \\
2.3 \%(8) \\
6.0 \%(56) \\
15.9 \%(56) \\
38.6 \%(136) \\
62.5 \%(220)\end{array}$ \\
\hline
\end{tabular}

\section{Measurement Model}

Confirmatory factor analysis (CFA) is used to assess the psychometric properties of the measures, including reliability and construct validity. We note that 82 respondents have never purchased stickers using the LINE app. Accordingly, only 270 records are included in the data analysis due to the differences in perceptions and behaviors between buyers and non-buyers. The factor loadings of the indicators are all above 0.5 and significant $(p<0.01)$, ranging between 0.563 and 0.955 , which indicates construct validity. We also examine the validity and reliability of the measures by computing Cronbach's alphas, composite reliabilities, and Average Variance Extracted (AVE) 
scores (see Table 2). The results strongly confirm the reliability of the measures. The alphas and composite reliability scores exceed 0.80, and all AVEs are over 0.50. All scores exceed the accepted rules of thumb (factor loadings $=0.70$; alphas $=0.80 ;$ AVEs
$=0.50)$. Table 3 shows the test results for discriminant validity. All AVEs are lower than the values of the squared correlations among the constructs in the corresponding rows and columns, indicating discriminant validity.

\begin{tabular}{|l|l|l|l|l|}
\hline \multicolumn{2}{|l}{ Table 2 - Dimensionality, reliability, and convergent validity statistics } \\
\hline Construct (no. of items) & $\begin{array}{l}\text { Factor loadings measurement } \\
\text { model (CFA) }\end{array}$ & alpha & $\begin{array}{l}\text { Composite } \\
\text { reliability }\end{array}$ & AVE \\
\hline Perceived functional value (4) & $0.923 ; 0.936 ; 0.919 ; 0.896$ & 0.845 & 0.9560 & 0.844 \\
\hline Perceived social value (8) & $\begin{array}{l}0.729 ; 0.718 ; 0.730 ; 0.586 ; 0.652 ; \\
0.635 ; 0.666 ; 0.656\end{array}$ & 0.914 & 0.930 & 0.624 \\
& $\begin{array}{l}0.656 ; 0.705 ; 0.730 ; 0.814 ; 0.885 ; \\
\text { Perceived emotional value (9) }\end{array}$ & 0.939 & 0.939 & 0.632 \\
\hline Satisfaction (4) & $0.886 ; 0.893 ; 0.797 ; 0.783$ & & \\
\hline Reference group acceptance (5) & $0.764 ; 0.799 ; 0.931 ; 0.846$ & 0.933 & 0.933 & 0.776 \\
\hline Personal innovativeness (4) & $0.851 ; 0.888 ; 0.882 ; 0.669 ; 0.828$ & 0.901 & 0.901 & 0.645 \\
\hline Purchase Intention (3) & $0.955 ; 0.952 ; 0.955$ & 0.896 & 0.896 & 0.684 \\
\hline
\end{tabular}

\section{Table 3 - Discriminant validity: AVEs versus cross-construct squared correlations}

\begin{tabular}{|c|c|c|c|c|c|c|c|}
\hline Construct & FV & SV & EV & SAT & RFG & II & $\mathrm{P}$ \\
\hline FV & 0.919 & & & & & & \\
\hline SV & $0.360^{\star \star}$ & 0.790 & & & & & \\
\hline EV & $0.440^{* *}$ & $0.615^{\star \star}$ & 0.795 & & & & \\
\hline SAT & $0.465^{\star *}$ & $0.592^{\star \star}$ & $0.760^{\star \star}$ & 0.881 & & & \\
\hline RFG & $0.291^{\star *}$ & $0.509^{\star \star}$ & $0.316^{\star \star}$ & $0.281^{* \star}$ & 0.803 & & \\
\hline II & $0.316^{\star *}$ & $0.370^{\star \star}$ & $0.341^{* \star}$ & $0.387^{\star *}$ & $0.171^{\star \star}$ & 0.829 & \\
\hline $\mathrm{PI}$ & $0.506^{\star *}$ & $0.504^{\star \star}$ & $0.543^{\star \star}$ & $0.597^{\star \star}$ & $0.442^{\star \star}$ & $0.437^{\star *}$ & 0.954 \\
\hline
\end{tabular}

Notes: $\mathrm{FV}=$ perceived function value; $\mathrm{SV}=$ perceived social value; $\mathrm{EV}=$ perceived emotional value; SAT = satisfaction; RFG = reference group acceptance; $I I=$ personal innovativeness; $\mathrm{PI}=$ purchase intention. ${ }^{* *} p<0.01$. The bold scores (diagonal) are the AVEs of the individual constructs. Off-diagonal scores are the squared correlations between constructs.

\section{Structural Model}

The study uses structural equation modeling (SEM) via partial least square (PLS) conducted with SmartPLS 2.0. Perceived value is composed of three reflective constructs: functional value, social value, and emotional value. We adopt SmartPLS's recommended two-stage approach with a reflective-formative indicators model to analyze the second-order constructs. Table 4 presents the main results. Hypotheses 1 to 4 are all supported. The influences of perceived value, satisfaction, reference group acceptance, and personal innovativeness on purchase intention are all significant.

\begin{tabular}{|l|l|l|}
\hline \multicolumn{2}{|l|}{ Table 4 - Hypothesis testing results $(\mathbf{n}=\mathbf{3 5 2})$} & Sign. \\
\hline Hypothesis & Path & $<0.001$ \\
\hline H1 & Perceived Value -> Purchase Intention & $<0.05$ \\
H2 & Satisfaction -> Purchase Intention & $<0.001$ \\
H3 & Reference Group -> Purchase Intention & $<0.001$ \\
H4 & Personal Innovativeness -> Purchase Intention & \\
\hline
\end{tabular}


The moderating effects of reference group acceptance and personal innovativeness are analyzed by multi-group comparison. Tables 5 and 6 show the moderating effects of reference group acceptance and personal innovativeness, respectively. The results show that hypotheses $5 a$ and $6 a$ are supported. The relationship between perceived value and purchase intention is enhanced by both reference group acceptance and personal innovativeness.
Hypotheses $5 \mathrm{~b}$ and $6 \mathrm{~b}$ are both partially supported. In the low reference group acceptance and low personal innovativeness groups, higher satisfaction increases consumers' purchase intention for stickers in the LINE app, but consumers' satisfaction is insensitive to purchase intention in the high reference group acceptance and high personal innovativeness groups.

\section{Table 5 - Test of moderating effect of reference group (H5a \& H5b )}

\begin{tabular}{|c|c|c|c|c|c|}
\hline $\begin{array}{l}\text { Reference } \\
\text { group }\end{array}$ & Path & Effect & $\begin{array}{l}\text { Standardized } \\
\text { estimate }\end{array}$ & t-value & p-value \\
\hline Low & $\begin{array}{l}\text { Perceived Value -> } \\
\text { Purchase Intention } \\
\text { Satisfaction -> } \\
\text { Purchase Intention }\end{array}$ & $\begin{array}{l}\text { Strengthened } \\
\text { Strengthened }\end{array}$ & $\begin{array}{l}0.216 \\
0.202\end{array}$ & $\begin{array}{l}1.995 \\
1.990\end{array}$ & $\begin{array}{l}{ }^{* \star} 0.047 \\
{ }^{* *} 0.047\end{array}$ \\
\hline High & $\begin{array}{l}\text { Perceived Value -> } \\
\text { Purchase Intention } \\
\text { Satisfaction -> } \\
\text { Purchase Intention }\end{array}$ & $\begin{array}{l}\text { Strengthened } \\
\text { Not Supported }\end{array}$ & $\begin{array}{l}0.278 \\
0.314\end{array}$ & $\begin{array}{l}3.167 \\
1.249\end{array}$ & $\begin{array}{l}{ }^{* * *} 0.002 \\
0.212\end{array}$ \\
\hline
\end{tabular}

Table 6 - Test of moderating effect of personal innovativeness (H6a \& $\mathrm{H} 6 \mathrm{~b}$ )

\begin{tabular}{|c|c|c|c|c|c|}
\hline $\begin{array}{l}\text { Personal } \\
\text { innovativeness }\end{array}$ & Path & Effect & $\begin{array}{l}\text { Standardized } \\
\text { estimate }\end{array}$ & t-value & p-value \\
\hline Low & $\begin{array}{l}\text { Perceived Value -> } \\
\text { Purchase Intention } \\
\text { Satisfaction -> } \\
\text { Purchase Intention }\end{array}$ & $\begin{array}{l}\text { Strengthened } \\
\text { Strengthened }\end{array}$ & $\begin{array}{l}0.216 \\
0.202\end{array}$ & $\begin{array}{l}1.995 \\
1.990\end{array}$ & $\begin{array}{l}{ }^{* *} 0.047 \\
{ }^{* *} 0.047\end{array}$ \\
\hline High & $\begin{array}{l}\text { Perceived Value -> } \\
\text { Purchase Intention } \\
\text { Satisfaction -> } \\
\text { Purchase Intention }\end{array}$ & $\begin{array}{l}\text { Strengthened } \\
\text { Not Supported }\end{array}$ & $\begin{array}{l}0.278 \\
0.314\end{array}$ & $\begin{array}{l}3.167 \\
1.249\end{array}$ & $\begin{array}{l}{ }^{* *} 0.002 \\
0.212\end{array}$ \\
\hline
\end{tabular}

\section{Discussion}

Our key findings are as follows. First, consumers' perceived value concerning virtual goods is critical to their purchase intention. Emotional and social values are two key components of perceived value. Functional value is less crucial. Consumers pay little attention to the function of virtual goods, such as the ability to communicate with friends more effectively or manage social relationships. Second, satisfaction, reference group acceptance, and personal innovativeness have a significant influence on purchase intention. The decision to purchase LINE stickers may depend on product features, consumers' attitude to innovative technology, and peer groups. LINE is a social platform that makes it simple for users to conduct social interactions. Thus, sticker users may become sticker buyers due to the influence of other users. Buying stickers gives access to fresh and personalized services as well as entertainment. These features induce consumers' intention to purchase them. Third, high personal innovativeness does not significantly enhance the relationship 
between satisfaction and purchase intention. If consumers' attitude to innovative technology is high enough, they tend to find a way to obtain stickers. For example, consumers may play LINE mobile games to earn tokens in exchange for stickers. A sophisticated consumer may know how to download foreign stickers for free by setting up a virtual private network (VPN). Hence, their intention to purchase stickers may not be influenced as easily as the intentions of those with low levels of personal innovativeness. Fourth, high reference group acceptance does not significantly enhance the relationship between satisfaction and purchase intention. Consumers at a high level of reference group acceptance are easily influenced by their family, friends, and peer groups. If they and their peer groups feel highly satisfied with the stickers, their intention to purchase them will be high. On the other hand, consumers at a low level of reference group acceptance may focus more on their product experience and satisfaction, significantly influencing purchase intention.

\section{Conclusion and Limitations}

We examine the intention to purchase virtual goods and the critical successful factors for LINE stickers. All of the hypotheses are supported, while hypotheses $5 b$ and $6 b$ are partially supported. The study shows that perceived value, satisfaction, reference group acceptance, and personal innovativeness are all positively associated with purchase intention. The moderation of reference group acceptance and personal innovativeness in the effect of perceived value and satisfaction on purchase intention is partially supported.

\section{Theoretical Implications}

This study offers the following theoretical implications. Frist, the study focuses on consumers' intentions and behaviors concerning virtual goods bought via in-app purchases on social network platforms. The results show the significant impacts of individual perception, personal characteristics, and social influence. The literature has explored consumers' behavior around in-app purchases of mobile/online games. Our findings increase our understanding of in-app purchases in the context of mobile/online social media. Second, perceived value is a second-order construct, and the importance of subconstructs varies depending on the context. For example, this study shows that most consumers consider emotional value and social value as the most important factors in their purchase decisions. Functional value is less important and is not a major issue on social network platforms. Third, the study compares between the effects of individual perception and social influence. We find that personal characteristics play a key role in in-app purchases on mobile social media. Consumers with high personal innovativeness tend to buy virtual goods without considering their product experience, as do consumers with high reference group acceptance.

\section{Practical Implications}

Our findings offer two implications for the providers of virtual goods on social network platforms. First, when consumers access virtual goods, providers should attempt to invoke consumers' happiness and enjoyment and enhance their selfpresentation and their sense of belonging, relationship, and acquaintance. For example, LINE stickers are effective surrogates for consumer communication. Stickers are also useful for improving consumers' purchase intention, as they can provide topics for group discussion or echo users' emotional responses. Ensuring that virtual goods are satisfactory and have positive electronic word-of-mouth could also induce users to purchase them. Second, consumers with high innovativeness will find a way to obtain free stickers. Hence, providers may consider how to increase users' perceived value and thus drive more 
exposure for their business-for example, by offering free and funny stickers in partnership with a cartoonist or building a platform that allows consumers to create their own stickers.

\section{Limitations}

This study has two limitations. First, its data were collected from the bulletin board system of PTT and Facebook. Thus, the sample may lack diversity, which may bias the results. We plan to expand the data sources in future work. Second, the study considers consumers' purchase intention only for LINE stickers. However, some virtual goods are offered in a freemium model on social network platforms such as Facebook and WeChat, whereby a free version is provided, and consumers can pay for a premium version after having tried the free one (e.g., LINE Music, LINE Game). We may compare consumers' purchase intentions among different social network platforms and consider multiple types of virtual goods in a future study.

\section{References}

Agarwal, R. and Karahanna, E. (2000). "Time Flies When You're Having Fun: Cognitive Absorption and Beliefs about Information Technology Usage," MIS Quarterly, 24(4), pp. 665-694.

Agarwal, R. and Prasad, J. (1998). "A Conceptual and Operational Definition of Personal Innovativeness in the Domain of Information Technology," Information Systems Research, 9(2), pp. 204-215.

Alvarez, S. (2012). "3 Ways Companies Profit from Virtual Goods," Retrieved from https://www.investopedia.com/fin ancial-edge/0512/3-ways-companiesprofit-from-virtual-goods.aspx.
Animesh, A., Pinsonneault, A., Yang, S. B. and Oh, W. (2011). "An Odyssey into Virtual Worlds: Exploring the Impacts of Technological and Spatial Environments on Intention to Purchase Virtual Products," MIS Quarterly, 35(3), pp. 789-810.

Annie, App. "IDC. 2014. Mobile App Advertising and Monetization Trends 2012-2017: The Economics of Free."

Bhattacherjee, A. (2001). "Understanding Information Systems Continuance: An Expectation-Confirmation Model," MIS Quarterly, 25(3), pp. 351-370.

Blackwell, R. D., Miniard, P. W. and Engel, J. F. (2001). Consumer Behavior 9th. South-Western Thomas Learning: Mason, $\mathrm{OH}$.

Bolton, R. N. and Drew, J. H. (1991). "A Multistage Model of Customers' Assessments of Service Quality and Value," Journal of Consumer Research, 17(4), pp. 375-384.

Bray, D. A. and Konsynski, B. R. (2007). "Virtual Worlds: Multi-disciplinary Research Opportunities," ACM SIGMIS Database, 38(4), pp. 17-25.

Chong, B., Yang, Z. and Wong, M. (2003, September). "Asymmetrical impact of trustworthiness attributes on trust, perceived value and purchase intention: a conceptual framework for cross-cultural study on consumer perception of online auction," Proceedings of the 5th International Conference on Electronic Commerce, ACM.

Churchill Jr, G. A. and Surprenant, C. (1982). "An Investigation into the Determinants of Customer Satisfaction," Journal of Marketing Research, 19(4), pp. 491-504.

Hamari, J. (2017). "Do Badges Increase User Activity? A Field Experiment on the Effects of Gamification," Computers in Human Behavior, 71, pp. 469-478. 
Hoonsopon, D. and Puriwat, W. (2016, June). "The impact of reference group on purchase intention: A case study in distinct types of shoppers," Rediscovering the Essentiality of Marketing: Proceedings of the 2015 Academy of Marketing Science (AMS) World Marketing Congress.

Jackson, J. D., Mun, Y. Y. and Park, J. S. (2013). "An Empirical Test of Three Mediation Models for the Relationship between Personal Innovativeness and User Acceptance of Technology," Information and Management, 50(4), pp. 154-161.

Jung, Y. and Pawlowski, S. D. (2014). "Virtual Goods, Real Goals: Exploring Means-End Goal Structures of Consumers in Social Virtual Worlds," Information and Management, 51(5), pp. 520-531.

Kim, H. W., Chan, H. C. and Gupta, S. (2007). "Value-based Adoption of Mobile Internet: An Empirical Investigation," Decision Support Systems, 43(1), pp. 111-126.

Kim, H. W., Chan, H. C. and Kankanhalli, A. (2012). "What Motivates People to Purchase Digital Items on Virtual Community Websites? The Desire for Online Self-presentation," Information Systems Research, 23(4), pp. 12321245.

Kim, H. W., Gupta, S. and Koh, J. (2011). "Investigating the Intention to Purchase Digital Items in Social Networking Communities: A Customer Value Perspective," Information and Management, 48(6), pp. 228-234.

Koeder, M. J. and Tanaka, E. (2017). "Game of chance elements in free-toplay mobile games. A freemium business model monetization tool in need of self-regulation?" 28th European Regional Conference of the International Telecommunications Society (ITS).
Kotler, P. (1994). Marketing management, analysis, planning, implementation, and control, Philip Kotler. London: Prentice-Hall International.

Kwon, H. K. and Seo, K. K. (2013). "Application of Value-based Adoption Model to Analyze SaaS Adoption Behavior in Korean B2B Cloud Market," International Journal of Advancements in Computing Technology, 5(12), pp. 368-373.

Lehdonvirta, V. (2009). "Virtual Item Sales as a Revenue Model: Identifying Attributes That Drive Purchase Decisions," Electronic Commerce Research, 9(1), pp. 97-113.

Lin, C. A. (2006). "Predicting Webcasting Adoption Via Personal Innovativeness and Perceived Utilities," Journal of Advertising Research, 46(2), pp. 228238.

Lin, L. Y. and Chen, Y. W. (2006). "The Moderating Effects of Reference Groups and Unanticipated Situational Factors between Purchase Intentions and Repurchase Decisions: An Empirical Study of Travellers on Taiwan Tourist Trains." Tamsui Oxford Journal of Management Sciences, 22(2), pp. 27-52.

Lu, J. (2014). "Are Personal Innovativeness and Social Influence Critical to Continue With Mobile Commerce?" Internet Research, 24(2), pp. 134-159.

Oliver, R. L. (1980). "A Cognitive Model of the Antecedents and Consequences of Satisfaction Decisions," Journal of Marketing Research, 17(4), pp. 460469.

Park, C. H. and Kim, Y. G. (2003). "Identifying Key Factors Affecting Consumer Purchase Behavior in an Online Shopping Context," International Journal of Retail and Distribution Management, 31(1), pp. 16-29. 
Parveen, F. and Sulaiman, A. (2008). "Technology Complexity, Personal Innovativeness and Intention to Use Wireless Internet Using Mobile Devices in Malaysia," International Review of Business Research Papers, 4(5), pp. 1-10.

Sweeney, J. C. and Soutar, G. N. (2001). "Consumer Perceived Value: The Development of a Multiple Item Scale," Journal of Retailing, 77(2), pp. 203-220.

Turner, R. H. (1956). "Role-taking, Role Standpoint, and Reference-group Behavior," American Journal of Sociology, 61(4), pp. 316-328.

Veloutsou, C. and Moutinho, L. (2009). "Brand Relationships through Brand Reputation and Brand Tribalism," Journal of Business Research, 62(3), pp. 314-322.
Verhagen, T., Feldberg, F., van den Hooff, B., Meents, S. and Merikivi, J. (2011). "Satisfaction with Virtual Worlds: An Integrated Model of Experiential Value," Information and Management, 48(6), pp. 201-207.

Wolfinbarger, M. and Gilly, M. C. (2001). "Shopping Online for Freedom, Control, and Fun," California Management Review, 43(2), pp. 34-55.

Yi, M. Y., Fiedler, K. D. and Park, J. S. (2006). "Understanding the Role of Individual Innovativeness in the Acceptance of IT-based Innovations: Comparative Analyses of Models and Measures," Decision Sciences, 37(3), pp. 393-426.

Zeithaml, V. A. (1988). "Consumer Perceptions of Price, Quality, and Value: A Means-End Model and Synthesis of Evidence," The Journal of Marketing, 52(3), pp. 2-22. 


\section{Appendix I: Questionnaire Items}

\begin{tabular}{|c|c|c|c|}
\hline Construct & ID & Item & Sources \\
\hline \multirow{4}{*}{$\begin{array}{l}\text { Perceived } \\
\text { Functional } \\
\text { Value }\end{array}$} & FV1 & $\begin{array}{l}\text { The stickers (digital items) sold here have an acceptable } \\
\text { standard quality. }\end{array}$ & \multirow[t]{4}{*}{$\begin{array}{l}\text { Kim } \\
(2011)\end{array}$} \\
\hline & FV2 & $\begin{array}{l}\text { The stickers (digital items) sold here are reliable in their } \\
\text { performance. }\end{array}$ & \\
\hline & FV3 & $\begin{array}{l}\text { The stickers (digital items) sold here are good in terms of } \\
\text { their overall excellence. }\end{array}$ & \\
\hline & FV4 & $\begin{array}{l}\text { The stickers (digital items) sold here possess a degree of } \\
\text { quality, which is satisfactory. }\end{array}$ & \\
\hline \multirow{8}{*}{$\begin{array}{l}\text { Perceived } \\
\text { Social Value }\end{array}$} & SV1 & $\begin{array}{l}\text { Using the stickers (digital items) sold here enhances my } \\
\text { self-image to others. }\end{array}$ & \multirow[t]{8}{*}{$\begin{array}{l}\text { Kim et al. } \\
(2011)\end{array}$} \\
\hline & SV2 & $\begin{array}{l}\text { Using the stickers (digital items) sold here improves my self- } \\
\text { expression to others. }\end{array}$ & \\
\hline & SV3 & $\begin{array}{l}\text { Using the stickers (digital items) sold here makes a good } \\
\text { impression on other people. }\end{array}$ & \\
\hline & SV4 & $\begin{array}{l}\text { Using the stickers (digital items) sold here improves the way } \\
\text { I am perceived. }\end{array}$ & \\
\hline & SV5 & $\begin{array}{l}\text { Using the stickers (digital items) sold here better enables me } \\
\text { to form interpersonal bonds with others. }\end{array}$ & \\
\hline & SV6 & $\begin{array}{l}\text { Using the stickers (digital items) sold here helps me } \\
\text { maintain my social relationships with others. }\end{array}$ & \\
\hline & SV7 & $\begin{array}{l}\text { Using the stickers (digital items) sold here helps me make } \\
\text { friends. }\end{array}$ & \\
\hline & SV8 & $\begin{array}{l}\text { Using the stickers (digital items) sold here enhances my } \\
\text { social relationship with others. }\end{array}$ & \\
\hline \multirow{9}{*}{$\begin{array}{l}\text { Perceived } \\
\text { Emotional } \\
\text { Value }\end{array}$} & EV1 & The stickers (digital items) sold here are lovely. & \multirow{9}{*}{$\begin{array}{l}\text { Kim et al. } \\
(2011)\end{array}$} \\
\hline & EV2 & The stickers (digital items) sold here reflect beauty. & \\
\hline & EV3 & The stickers (digital items) sold here aesthetically appealing. & \\
\hline & EV4 & $\begin{array}{l}\text { The stickers (digital items) sold here have attractive } \\
\text { aesthetic features. }\end{array}$ & \\
\hline & EV5 & Using the stickers (digital items) sold here is fun. & \\
\hline & EV6 & $\begin{array}{l}\text { Using the stickers (digital items) sold here is interesting to } \\
\text { me. }\end{array}$ & \\
\hline & EV7 & $\begin{array}{l}\text { Using the stickers (digital items) sold here stimulates my } \\
\text { curiosity. }\end{array}$ & \\
\hline & EV8 & $\begin{array}{l}\text { Using the stickers (digital items) sold here arouses my } \\
\text { imagination. }\end{array}$ & \\
\hline & EV9 & $\begin{array}{l}\text { Using the stickers (digital items) sold here keeps me } \\
\text { absorbed. }\end{array}$ & \\
\hline \multirow[t]{4}{*}{ Satisfaction } & SAT1 & $\begin{array}{l}\text { I am satisfied with my overall experienced of sticker use in } \\
\text { the LINE app. }\end{array}$ & \multirow{4}{*}{$\begin{array}{l}\text { Oliver (1980); } \\
\text { Bhattacherjee } \\
\text { (2001) }\end{array}$} \\
\hline & SAT2 & $\begin{array}{l}\text { I am pleased with my overall experienced of sticker use in } \\
\text { the LINE app. }\end{array}$ & \\
\hline & SAT3 & $\begin{array}{l}\text { I am contented with my overall experienced of sticker use in } \\
\text { the LINE app. }\end{array}$ & \\
\hline & SAT4 & $\begin{array}{l}\text { I am delighted with my overall experienced of sticker use in } \\
\text { the LINE app. }\end{array}$ & \\
\hline \multirow{3}{*}{$\begin{array}{l}\text { Reference } \\
\text { Group } \\
\text { Acceptance }\end{array}$} & RFG1 & $\begin{array}{l}\text { I would buy stickers in the LINE app because I am sure that } \\
\text { my friends approve of it. }\end{array}$ & \multirow{3}{*}{$\begin{array}{l}\text { Veloutsou \& } \\
\text { Moutinho } \\
\text { (2009) }\end{array}$} \\
\hline & RFG2 & $\begin{array}{l}\text { am very loyal to stickers in the LINE app because my } \\
\text { friends also use it. }\end{array}$ & \\
\hline & RFG3 & My friends buy stickers in the LINE app and I buy it too just & \\
\hline
\end{tabular}




\begin{tabular}{|c|c|c|c|}
\hline & & because I want to like them. & \\
\hline & RFG4 & $\begin{array}{l}\text { I achieve a sense of belonging by buying the same stickers } \\
\text { in the LINE app my friends buy. }\end{array}$ & \\
\hline & RFG5 & I often discuss with friends about stickers in the LINE app. & \\
\hline \multirow{4}{*}{$\begin{array}{l}\text { Personal } \\
\text { Innovativeness }\end{array}$} & II1 & $\begin{array}{l}\text { If I heard about a new information technology, I would look } \\
\text { for ways to experiment with it. }\end{array}$ & \multirow{4}{*}{$\begin{array}{l}\text { Agarwal \& } \\
\text { Karahanna } \\
(2000)\end{array}$} \\
\hline & II2 & $\begin{array}{l}\text { In general, I am hesitant to try out new information } \\
\text { technologies. }\end{array}$ & \\
\hline & II3 & $\begin{array}{l}\text { Among my peers, I am usually the first to try out new } \\
\text { information technologies. }\end{array}$ & \\
\hline & 114 & I like to experiment with new information technologies. & \\
\hline \multirow{3}{*}{$\begin{array}{ll}\text { Intention } & \text { to } \\
\text { Purchase }\end{array}$} & PI1 & $\begin{array}{l}\text { The probability that I would consider buying digital items } \\
\text { form XXX within the next } 6 \text { months is high. }\end{array}$ & \multirow[t]{3}{*}{$\begin{array}{l}\text { Kim } \\
(2011)\end{array}$} \\
\hline & $\mathrm{PI} 2$ & $\begin{array}{l}\text { My willingness to buy a digital item from XXX within the next } \\
6 \text { months is high. }\end{array}$ & \\
\hline & $\mathrm{PI3}$ & $\begin{array}{l}\text { The likelihood of my purchasing a digital item from XXX } \\
\text { within the next } 6 \text { months is high. }\end{array}$ & \\
\hline
\end{tabular}

\section{About the Authors}

Yu-Chen Yang is an Assistant Professor in Information Management at National Sun Yat-sen University in Taiwan. Prior to joining National Sun Yat-sen University, he earned his Ph.D. in Information Systems from the University of Florida in 2013. Dr. Yang has received the Sayling Wen's Award for young outstanding researchers in service science for the year of 2015, and Sun Yat-sen Management Research Award in 2017. At National Sun Yat-sen University, he has taught electronic commerce, managerial math and supply chain management and has received three times the Teaching Excellent Award. His research interests include e-commerce, economics of information systems, and data mining. His work have been published in top-tier academic journals, including MIS Quarterly, Journal of Management Information Systems, and European Journal of Operational Research.

Li-Ting Huang is working as an associate professor in the department of Information Management at Chang Gung University in Taiwan. She is also serving as an associate research fellow in the division of physical medicine and rehabilitation at Chang Gung
Memorial Hospital in Linkuo, Taiwan. Currently her research focuses on electronic/social/mobile commerce, customer relationship management, and supply chain management. Dr. Huang published various papers in the international journals, such as Computers \& Industrial Engineering, Journal of Business Research, Cyberpsychology, Behavior, and Social Networking, New Review of Hypermedia and Multimedia, Pacific Asia Journal of the Association for Information Systems, Lecture Notes in Computer Science, International Journal of Strategic Decision Sciences, Journal of Information Management, Management Review, Sun Yat-Sen Management Review, etc.

Yu-Ting Su is a programmer in the information department of the E.SUN commerical bank, Ltd. Prior to joining the E.Sun bank, she obtained her master degree in information management at National Sun Yat-sen University in 2015 and her bachelor degree in information management at Chang Gung University in 2013. While at National Sun Yat-sen University, she focused on the study of mobile commerce and provided an analysis of the usage of mobile messengers. 